\title{
TRONDHEIM NATURAL RADIOCARBON MEASUREMENTS VII
}

\author{
STEINAR GULLIKSEN, REIDAR NYDAL, and KNUT LÖVSETH
}

Radiological Dating Laboratory, The Norwegian Institute of Technology, The University of Trondheim, Norway

\section{INTRODUCTION}

Most dates in this list were obtained in the period 1970 to 1972. Treatment of samples and counting equipment have remained essentially the same as described previously (R, 1972, v 14, p 418-419).

Counting equipment and improvements are described in more detail by Gulliksen (1972). Our counters 2, 5 and 6 now have backgrounds/recent standard net counts of respectively $.8 \mathrm{cpm} / 19.3 \mathrm{cpm}, 1.1 \mathrm{cpm} / 11.7 \mathrm{cpm}$, and $.55 \mathrm{cpm} / 7.6 \mathrm{cpm}$. Guard Counter GM3 (Nydal, 1965) shielding our Counter 2, has been continuously working for 3 years without refilling or purification of the propane counting gas (1.2atm). Gyttja samples are now dated by using the $\mathrm{NaOH}$-soluble fraction whenever the quantity of sample material is sufficient.

Ages are calculated by applying the Libby value $5570 \pm 30$ years, for the ${ }^{14} \mathrm{C}$ half life, and using $95 \%$ of NBS oxalic acid activity as contemporary standard referring to AD 1950 . Errors quoted $( \pm 1 \sigma)$ include counting uncertainties for sample, standard, and background. $\delta^{13} \mathrm{C}$ values reported are relative to $\mathrm{PDB}$, and corrections for deviations from $0 \%$ relative PDB are applied for shell samples.

\section{ACKNOWLEDGMENTS}

The authors wish to thank collectors and submitters of the samples for their collaboration in preparing the manuscript. ${ }^{13} \mathrm{C} /{ }^{12} \mathrm{C}$ ratios were measured by R Ryhage, Karolinska Inst, Stockholm. Further thanks to Elsa Riiser and Fred Skogseth for sample treatment. Financial support from The Norwegian Research Council for Science and the Humanities is fully acknowledged.

\section{SAMPLE DESCRIPTIONS}

\section{GEOLOGIC SAMPLES}

\section{Norway}

\section{Interstadial and interglacial samples}

\section{Flåte series, Vaksdal}

Marine shells from +40 to $45 \mathrm{~m}$ in Flåte, Trengereid, Vaksdal $\left(60^{\circ}\right.$ $\left.26^{\prime} \mathrm{N}, 5^{\circ} 35^{\prime} \mathrm{E}\right)$. T-1161 I and II from silt embedded in till, T-1162 from till. Coll and subm 1971 by Jan Mangerud, Dept Geol, Univ Bergen. Comment (JM): site is farthest inside the Younger Dryas end moraines in Hordaland where Alleröd dated sediments are found. Sediments overridden by ice during Younger Dryas (Aarseth and Mangerud, 1974; Mangerud, 1973). 


\section{T-1161 I. Flåte 1}

Balanus balanus from depth $3 \mathrm{~m}$.

\section{T-1161 II. Flåte 2}

Chlamys islandicus from depth $3 \mathrm{~m}$.

\section{T-1162. Flåte 3}

Outer (a) and inner (b) fraction of Balanus balanus from depth $4 \mathrm{~m}$.

\section{T.1021. Os}

Marine shells from $+50 \mathrm{~m}$ in Os, Hordaland $\left(60^{\circ} 11^{\prime} \mathrm{N}, 5^{\circ} 29^{\prime} \mathrm{F}\right)$ From shelly sand at depth $3 \mathrm{~m}$, probably overridden by ice. Coll 1969 and subm 1970 by J Mangerud. Comment (JM): many species of marine shells found (Aarseth and Mangerud, 1974; Mangerud, 1973).

\section{T-1022. Hjellestad, Bergen}

(a) $11,990 \pm 200$ 10,040 BC $\delta^{13} \mathrm{C}=+1.7 \%$

(b) $11,880 \pm 120$ 9930 BC

$\delta^{13} C=+1.6 \%$

Inner (b) and outer (a) fraction of marine shells (Mya truncata), from clay underlying till in Younger Dryas end moraines at Hjellestad, Bergen, Hordaland $\left(60^{\circ} 15^{\prime} \mathrm{N}, 5^{\circ} 15^{\prime} \mathrm{E}\right)$. Coll at +10 to $20 \mathrm{~m}$, ca $2 \mathrm{~m}$ below surface. Coll and subm 1970 by J Mangerud. Comment (JM): dates indicate site was deglaciated early in Alleröd. Ice advance during Younger Dryas reached site (Aarseth and Mangerud, 1974; Mangerud, 1973).

\section{T-1049. Herdla Moraine}

$10,540 \pm 130$

Marine shells (Mya truncata) from seashore sec in Herdla Moraine, Herdla, Asköy, Hordaland (60 $34^{\circ}$ N, $\left.4^{\circ} 87^{\prime} \mathrm{E}\right)$. Coll and subm 1970 by $\mathrm{J}$ Mangerud. Comment (JM): shells from below ice-front sediments. Indicates Herdla moraines are of Late Younger Dryas age (Aarseth and Mangerud, 1974; Mangerud, 1973).

\section{T.743/II. Hensmoen 2}

Stump of Spruce from North Hen sandpit, Ringerike, Buskerud. Coll 1968 by L Kjemperud; subm 1969 by T Nygaard, Univ Oslo. Posi- 
tion in pit approx as for stump coll 1966, dated to 48,000 ${ }_{-2000}^{+4000}$ BP (T743, R, 1970, v 12, p 215). Lab comment: dated to check T-743. Probably of same age, ie, activity found in T-743 might not be real. T-743/II calculated with a confidence limit of $2 \sigma$.

2. Postglacial samples

T-1160. Lekvenvann

$7710 \pm 100$

5760 BC

Gyttja from Lekvenvann at $+37 \mathrm{~m}$, Os, Hordaland $\left(60^{\circ} 10^{\prime} \mathrm{N}, 5^{\circ} 27^{\prime}\right.$ E). Sample coll with $54 \mathrm{~mm}$ piston sampler 6.80 to $6.85 \mathrm{~m}$ below surface. In pollen diagram Alnus increases from $3 \%$ to ca $40 \%$ within $.10 \mathrm{~m}$; sample from lower $.05 \mathrm{~m}$ of rise. Coll and subm 1971 by J Mangerud.

\section{Engerdal series}

Peat from Engerdal, Hedmark $\left(61^{\circ} 38^{\prime} \mathrm{N}, 11^{\circ} 45^{\prime} \mathrm{E}\right)$ dating Holocene soil and vegetational development. Samples from pollen analyzed sec in traverse from valley floor at $+550 \mathrm{~m}$ to alpine region $(+1040 \mathrm{~m})$. One sec, in sloping spring fen at $+955 \mathrm{~m}$, is chosen as "type locality". Coll and subm 1970-1972 by Rolf Sörensen, Inst Geol, Norwegian Inst of Agric, Ås.

\section{T-981. Holbekkjölen}

$3310 \pm 170$

From depth $1.40 \mathrm{~m}$, underlying main recurrence surface. Watershed fen at $+815 \mathrm{~m}$, slightly ombrotrophic in parts. Comment (RS): spruce expansion overlying recurrence surface (Tallantire, 1972; Lundqvist, 1951; 1969).

T-1126. Snerta

$6850 \pm 230$ 4900 BC

Basal sediments from dead ice depression at depth $4.90 \mathrm{~m}$ on margin of valley floor $(+557 \mathrm{~m})$. Comment $(\mathrm{RS})$ : age is minimum for last ice remains in central E Norway.

\section{T-1174. Römundfjell I}

$1660 \pm 80$

From depth $.45 \mathrm{~m}, .05 \mathrm{~m}$ above main recurrence surface, dating spruce expansion. Sloping spring fen at $+955 \mathrm{~m}$ in sub-alpine region, slightly above forest limit.

\section{T-1175. Römundfjell II}

$5850 \pm 100$

From depth $.75 \mathrm{~m}$ at $+955 \mathrm{~m}$, dating Alnus maximum (27\% AP). Comment (RS): date agrees well with results from Jämtland (Lundqvist, 1969).

\section{T-1317. Römundfjell III}

$$
\begin{aligned}
& 3320 \pm 80 \\
& 1370 \text { BC }
\end{aligned}
$$

From depth $.55 \mathrm{~m}, .05 \mathrm{~m}$ below main recurrence surface. Comment (RS): a hiatus of ca $1800 \mathrm{yr}$ is evident in this sec and same development seems likely for whole region, $c f$ T-981, -1174 . 


\section{T-1318. Römundfjell IV}

$8380 \pm 140$

Basal organic sediment at depth $.95 \mathrm{~m}$. Comment (RS): date agrees well with results from Jämtland (Lundqvist, 1969).

\section{T-1176. Skjerbekkdalen I}

$$
1180 \pm 70
$$

From depth $.35 \mathrm{~m}$, dating spruce expansion. Eroded spring fen in spruce forest at $+870 \mathrm{~m}$. Comment (RS): surprisingly late spruce expansion in area where soil and local climate should be most favorable.

T-1316. Skjerbekkdalen II

$$
2940 \pm 170
$$

1990 BC $+870 \mathrm{~m}$

Basal organic sediment at depth $.7 \mathrm{~m}$ above thin podzolic layer at

\section{Sauherad series}

Marine mollusks from Sauherad, Telemark. Coll and subm 1972 by Dagfinn Trömborg, Telemark District Academy.

\section{T-1249. Gvåla}

(a) $7810 \pm 110$

5860 вс

$\delta^{13} \mathrm{C}=+0.3 \%$

\section{T-1249. Grala}

Outer fraction (a) and inner

(b) $7910 \pm 120$ 5960 BC $\delta^{13} \mathrm{C}=+0.3 \%$ $\left.18^{\prime} \mathrm{E}\right)$ at $+35 \mathrm{~m}$, depth $1.2 \mathrm{~m}$.

\section{T-1250. Gyvihaug}

(a) $7440 \pm 110$ 5490 BC $\delta^{13} \mathrm{C}=+1.3 \%$

(b) $7620 \pm 160$ $5670 \mathrm{BC}$ $\delta^{13} \mathrm{C}=+2.0 \%$ 。

Outer fraction (a) and inner fraction (b) from Gyvihaug $\left(59^{\circ} 25^{\prime} \mathrm{N}\right.$, $\left.9^{\circ} 19^{\prime} \mathrm{E}\right)$ at $+32 \mathrm{~m}$, depth $2 \mathrm{~m}$.

\section{Akershus series}

Gyttja and shells from different parts of Akershus, dating Holocene sea-level changes. Shells from "Tapes" level and Aker substage shore level date shoreline-relation diagram for Oslo region. Sea-level curve for Ås-Ski area is based on shell, gyttja and wood dates. Coll and subm 1971 and 1972 by R Sörensen (Andrews, 1969; Danielsen, 1970; Hafsten, 1956; Undås, 1950).

\section{T-1173. Bollerudmåsan}

$9180 \pm 180$

Gyttja from depth $6.8 \mathrm{~m}$ in Bollerudmåsan $\left(59^{\circ} 43^{\prime} \mathrm{N}, 10^{\circ} 48^{\prime} \mathrm{E}\right)$. Large ombrotrophic bog dammed by end moraines in both ends at 
$+170 \mathrm{~m}$. Comment (RS): date younger than expected; might indicate a hiatus of late Pre-Boreal/Early Boreal age.

\section{T-1319. Bråtenmyra}

$$
9590 \pm 150
$$$$
7640 \mathrm{BC}
$$

From basal sediments at depth $1.25 \mathrm{~m}$ in Bråtenmyra at $+147 \mathrm{~m}\left(59^{\circ}\right.$ $44^{\prime} \mathrm{N}, 10^{\circ} 51^{\prime} \mathrm{E}$. Sample is from light gray gyttja overlying brackishmarine clay, Mytilus shells $.15 \mathrm{~m}$ below gyttja/clay boundary. Coll 1972 by J M Östby.

\section{T-1377. Bunnefjorden}

$$
\begin{gathered}
\text { (a) } 2220 \pm 80 \\
\mathbf{2 7 0} \text { вС } \\
\delta^{13} C=-0.3 \% \\
\text { (b) } \mathbf{2 4 3 0} \pm \mathbf{1 2 0} \\
\mathbf{4 8 0} \text { вС } \\
\delta^{13} C=+1.3 \%
\end{gathered}
$$

Outer fraction (a) and inner fraction (b) of Modiolus shells from depth $3.75 \mathrm{~m}$ in beach terrace at $+5 \mathrm{~m}$ at Bunnefjorden, Frogn $\left(59^{\circ} 43^{\prime} \mathrm{N}\right.$, $10^{\circ} 43^{\prime}$ E). Sample found with many Scrobicularia shells in dark, layered silt and fine sand below large mudflow. Comment (RS): shell bearing sediments considerably older than beach terrace. Dates approx age of mudflow, which must correspond to a sudden reduction of level of Lake Årungen, $1 \mathrm{~km}$ upstream.

\section{T-1378. Vestby}
(a) $6730 \pm 100$ 4780 BC$$
\delta^{13} \mathrm{C}=0 \%
$$
(b) $6770 \pm 100$ $4820 \mathrm{BC}$
$\delta^{13} C=+0.3 \%$

Outer fraction (a) and inner fraction (b) of shells from oyster-shell deposit at depth $.60 \mathrm{~m}$ with Tapes decussatus, and Mytilus-Littorina gravel in Vestby $\left(59^{\circ} 36^{\prime} \mathrm{N}, 10^{\circ} 46^{\prime} \mathrm{E}\right)$ at $+55 \mathrm{~m}$.

\section{Slidreåsen series}

Peat and gyttja from Vestre Slidre, Oppland. Coll 1971 by Kari Henningsmoen, Wencke Slomann, Helge Irgens Höeg; subm 1972 by H I Höeg, Inst Geol, Univ Oslo (Höeg, in press; Slomann, 1971).

\section{T-1478. Gardberg .20 to $.25 m$, peat}

$$
350 \pm 110
$$

From bog $1.975 \mathrm{~m}$ deep at Fardberg $\left(61^{\circ} 05^{\prime} \mathrm{N}, 9^{\circ} 01^{\prime} \mathrm{E}\right)$ at $+680 \mathrm{~m}$. Depth .20 to $.25 \mathrm{~m}$. Comment $(\mathrm{HIH})$ : dates beginning of recent farming period in Slidreåsen.

T-1338. Gardberg .45 to $.50 \mathrm{~m}$, gyttja

$$
1690 \pm 110
$$

Comment $(\mathrm{HIH})$ : dates most intensive farming period. 
T-1339. Gardberg .70 to $.75 \mathrm{~m}$, gyttja

$\mathbf{3 4 4 0} \pm \mathbf{1 2 0}$

Comment (HIH): dates 1st traces of a farming culture.

1490 BC

T-1479. Tvenge .95 to $1.05 \mathrm{~m}$, peat

$1990 \pm 80$

40 BC

Peat from bog $6.5 \mathrm{~m}$ deep near Tvengehögd $\left(61^{\circ} 05^{\prime} \mathrm{N}, 9^{\circ} 02^{\prime} \mathrm{E}\right)$ at $+900 \mathrm{~m}$. Comment $(\mathrm{HIH})$ : dates beginning of Picea-curve; definite rise of Picea was later, ca AD 1000.

T-1340. Tvenge 1.96 to $2.05 \mathrm{~m}$, peat

$3380 \pm 120$

1430 вC

Comment (HIH): dates earliest farming culture in Slidreåsen. Decline in Alnus and QM, and rise in NAP, especially Cyperaceae.

T-1480. Tvenge 2.95 to $3.05 \mathrm{~m}$, gyttja

$5330 \pm 160$

Comment (HIH): dates decline in Alnus and rise in NAP.

T-1481. Tvenge 3.95 to $4.05 \mathrm{~m}$, gyttja

$6880 \pm 80$

Comment (HIH): dates Ulmus maximum.

4930 BC

T-1482. Tvenge 5.48 to $5.58 \mathrm{~m}$, gyttja

$10,230 \pm 260$

8390 BC

Comment (HIH): dates oldest organic deposits. Sample contained pollen from Alnus and QM, indicating that sample cannot be older than ca 7500 yr вP.

\section{T-1483. Slidre 0.95 to $1.05 \mathrm{~m}$, peat}

$1540 \pm 90$

From bog $5.7 \mathrm{~m}$ deep near Slidrestöl $\left(61^{\circ} 06^{\prime} \mathrm{N}, 9^{\circ} 00^{\prime} \mathrm{E}\right)$ at $+720 \mathrm{~m}$. Comment $(\mathrm{HIH})$ : dates forest clearing period in Slidreåsen, which starts a little earlier, at same time as beginning of continuous Picea curve. Definite rise of Picea came later, ca AD 1000.

T-1484. Slidre 4.03 to $4.13 \mathrm{~m}$, gyttja

$9670 \pm 570$

Comment (HIH): dates oldest organic deposits and immigration of Ulmus and Alnus. Pollen content indicates that sample cannot be older than ca 7500 yr BP.

\section{Skaitidalen series}

Peat and gyttja from Skaitidalen, Saltdal, Nordland. Coll 1970 and subm 1971 by H I Höeg (1972).

T-1095. Myr I, .94 to $1.09 \mathrm{~m}$, peat

$4230 \pm 170$ 2280 BC

From bog $1.25 \mathrm{~m}$ deep $\left(66^{\circ} 52^{\prime} \mathrm{N}, 15^{\circ} 48^{\prime} \mathrm{E}\right)$ at $+580 \mathrm{~m}$, depth .94 to $1.09 \mathrm{~m}$. Comment $(\mathrm{HIH})$ : dates oldest organic deposits. Deterioration of climate is seen in pollen diagram as a Cyperaceae peak between .88 and $.77 \mathrm{~m}$. 
T-1096. Myr C, 2.05 to $2.15 \mathrm{~m}$, peat

$3510 \pm 170$

1560 вC

From $4.20 \mathrm{~m}$ deep bog at $+640 \mathrm{~m}\left(66^{\circ} 54^{\prime} \mathrm{N}, 15^{\circ} 50^{\prime} \mathrm{E}\right)$. Comment (HIH): dates decline of Alnus.

T-1097. Myr C, 3.10 to $3.20 \mathrm{~m}$, gyttja

$4680 \pm 180$

Comment (HIH): dates beginning of climatic deterioration corresponding to a Cyperaceae peak, and also a Pinus decline.

T-1098. Myr C, 4.10 to $4.20 \mathrm{~m}$, gyttja

$7260 \pm 160$

Comment (HIH): dates oldest sediments and rise of Alnus.

T-1099. Myr F, 3.85 to $3.95 \mathrm{~m}$, gyttja

$11,440 \pm 480$

9490 вС

From $3.95 \mathrm{~m}$ deep bog $\left(66^{\circ} 49^{\prime} \mathrm{N}, 15^{\circ} 50^{\prime} \mathrm{E}\right)$ at $+550 \mathrm{~m}$. Comment $(\mathrm{HIH})$ : dates oldest sediments containing pollen from typical Pre-Boreal vegetation (Betula nana, Hippophaë, Salix, Rumex, Saxifraga, and Caryophyllaceae). Date too old, Alleröd not expected in this area.

\section{Breiavatnet series}

Gyttja and shell from bottom mud in Lake Breiavatnet at $+4.2 \mathrm{~m}$ in city of Stavanger, Rogaland $\left(58^{\circ} 58^{\prime} \mathrm{N}, 5^{\circ} 44^{\prime} \mathrm{E}\right)$. Series gives the age of Lake Breiavatnet (time of isolation from sea), and reveals human impact on vegetation during last $3000 \mathrm{yr}$. Coll 1971 and subm 1972 by Asbjörn Simonsen, Stavanger Mus (Simonsen, 1971).

T-1163. Breiavatnet $1,4.45$ to $4.50 \mathrm{~m}$, gyttja AD 1300

$650 \pm 100$

From depth 4.45 to $4.50 \mathrm{~m}$ below water surface. Comment (AS): dates a sharp decline in cereal pollen.

T-1283. Breiavatnet $2,4.80 \mathrm{~m}$, gyttja

$$
1190 \pm 100
$$
AD 760

Comment (AS): dates low frequency of cereal pollen in Merovinger period, reflecting low agricultural activity.

T-1164. Breiavatnet $3,5.25$ to $5.50 \mathrm{~m}$, gyttja

$$
1780 \pm 290
$$

Comment (AS): dates marked increase in cereal pollen, reflecting higher agricultural activity in Great Migration period.

T-1341. Breiavatnet $4,5.45 \mathrm{~m}$, gyttja

$2580 \pm 100$

$630 \mathrm{BC}$

T-1165. Breiavatnet 5, 5.65m, gyttja

$3090 \pm 160$

1140 BC

Comment (AS): dates transition layer of marine/brackish gyttja.

T-1284 II. Breiavatnet $6,6.75 \mathrm{~m}$, gyttja

$3150 \pm 200$

Comment (AS): decline of oak pollen.

$1200 \mathrm{BC}$ 
T-1284 I. Breiavatnet 6A, 6.75m, shell

$2670 \pm 110$

Shell fragments in gyttja of T-1284 II.

$720 \mathrm{BC}$

$\delta^{13} C=+0.2 \%$

$2670 \pm 80$

T-1332. Breiavatnet 6A, 6.75m, shell

$720 \mathrm{BC}$

$\delta^{13} C=+0.2 \%$ o

Shells (Ostrea edulis) embedded in gyttja of T-1284 II. Comment (AS): shells might have been pressed down from younger layer by core sampler.

\section{Eigeröy series}

Charcoal (Alnus) and peat from $1 \mathrm{~m}$ deep bog at $+5 \mathrm{~m}$ in Gjedlestadvige, Eigersund, Rogaland (58 25' N, $5^{\circ} 59^{\prime} \mathrm{E}$ ). Bog situated close to several dwelling sites from Mesolithic and later periods; series dates vegetational development in area. Two layers of charcoal reflect forest clearing. Coll 1971 and subm 1972 by A Simonsen (1972).

\section{T-1285. Eigeröy $1, .17$ to $.20 \mathrm{~m}$, charcoal}

$2120 \pm 100$

From depth .17 to $.20 \mathrm{~m}$. Comment (AS): dates last and final forest clearing in area, not coinciding with traditional Sub-Boreal/Sub-Atlantic transition.

\section{T-1167. Eigeröy $2, .23$ to .31m, charcoal}

$3340 \pm 80$

Comment (AS): dates 1st, incomplete forest clearing.

1390 BC

\section{T-1286. Eigeröy $3, .75$ to $.80 \mathrm{~m}$, peat}

$5810 \pm 160$

Upper part of peat under marine sand.

3860 BC

\section{Hardangervidda peat development series}

Peat and wood from the mountainous Hardangervidda area in $S$ Norway. Series date peat development in area, also used in pollen analytic and archaeologic studies. All samples are cut out of open profiles. Coll and subm 1970 to 1972 by Dagfinn Moe, Arthur Fasteland, and F E Wielgolaski, The Hardangervidda project for interdisciplinary cultural research. Comment (DM): dates correlate well with expected ages (Moe, 1973a, b).

T-1080. Halnelaegeret 1

$4860 \pm 90$

Peat from depth $80 \mathrm{~m}$ in Eidfjord, Hordaland $\left(60^{\circ} 25^{\prime} \mathrm{N}, 7^{\circ} 42^{\prime} \mathrm{E}\right)$ at $+1140 \mathrm{~m}$.

T-999. Halnelaegeret 2

$3510 \pm 90$

Peat from depth $1.4 \mathrm{~m}$.

$1560 \mathrm{BC}$ 
T-1079. Stigstuv 1

$5090 \pm 180$

Wood (Salix) from depth $.50 \mathrm{~m}$ in Eidfjord, Hordaland $\left(60^{\circ} 19^{\prime} \mathrm{N}\right.$, $\left.7^{\circ} 37^{\prime} \mathrm{E}\right)$, at $+1310 \mathrm{~m}$.

\section{T-1140. Stigstuv 2}

$8000 \pm 130$

Peat from depth .74 to $.75 \mathrm{~m}$.

$6050 \mathrm{BC}$

\section{T-1141. Stigstuv 3}

$5150 \pm 90$

Peat from depth .51 to $.52 \mathrm{~m}$.

3200 BC

\section{T-1081. Ustetind 1}

$5870 \pm 150$

Peat from depth $.60 \mathrm{~m}$ in Hol, Buskerud $\left(60^{\circ} 29^{\prime} \mathrm{N}, 8^{\circ} 07^{\prime} \mathrm{E}\right)$, at $+1310 \mathrm{~m}$.

3920 BC

\section{T-1554. Ustetind 2}

$1400 \pm 80$

Peat from depth .15 to $.16 \mathrm{~m}$. AD 550

T-1195. Vetle Fjellsetmyr 1

$4870 \pm 90$

Peat from depth .95 to $.97 \mathrm{~m}$ in Hol, Buskerud $\left(60^{\circ} 28^{\prime} \mathrm{N}, 8^{\circ} 10^{\prime} \mathrm{E}\right)$, at $+1135 \mathrm{~m}$.

T-1196. Vetle Fjellsetmyr 2

$7790 \pm 210$

Peat from depth 1.55 to $1.57 \mathrm{~m}$.

$\mathbf{5 8 4 0 ~ B C}$

II. ARCHAEOLOGIC SAMPLES

Norway

\section{Settlement sites}

\section{Hardangervidda Stone age series}

Charcoal and bone from several sites in different parts of the Hardangervidda mountain plateau in S Norway intended to give an absolute chronology for different stages of man's exploitation of area in pre-metal time. Coll 1970 to 1972 by Svein Indrelid and S Bang Andersen; subm 1970 to 1972 by S Indrelid, Univ Bergen (Indrelid, 1973).

\section{T-1000. Hein 85}

$7450 \pm 350$ 5500 BC

Charcoal from depth $.12 \mathrm{~m}$ at Heintjern, Buskerud $\left(60^{\circ} 22^{\prime} \mathrm{N}, 7^{\circ} 55^{\prime}\right.$ E) at $+1112 \mathrm{~m}$. From hearth of Stone age site with thin cultural layer. Artifacts made of quartz. Few tools. Comment (SI): character of raw material and chipping technique indicate Mesolithic age, but do not exclude other periods. 
1289. Hein 76

$7020 \pm 140$

Charcoal from depth .08 to $.10 \mathrm{~m}$ at Övre Hein, Buskerud $\left(60^{\circ} 22^{\prime} \mathrm{N}\right.$, $\left.7^{\circ} 52^{\prime} \mathrm{E}\right)$ at $+1113 \mathrm{~m}$. Comment (SI): finds are of same character as those from $\mathrm{T}-1000$.

\section{T-1003. Hein 33/1}

$5920 \pm 200$

Charcoal from depth .55 to $.58 \mathrm{~m}$ at Halnefjorden, Buskerud $\left(60^{\circ} 22^{\prime}\right.$ $\mathrm{N}, 7^{\circ} 44^{\prime} \mathrm{E}$ ) at $+1132 \mathrm{~m}$. Comment (SI): site Hein 33 was stratified, and it was archaeologically possible to distinguish at least 2 phases of settlement, an older pre-slate phase (Levels IV and V) and a younger slate phase (Levels I and II). In both phases were found points of single edged, oblique edged, and tanged types. Date of T-1003 (Level V) indicates that tanged points were used in this area in late Mesolithic time, before slate phase.

T-1005. Hein $33 / 2$

$5150 \pm 130$ $3200 \mathrm{BC}$

Charcoal from depth $.20 \mathrm{~m}$, Level III (transition pre-slate/slate). Small tanged points, oblique, and single edged points abundant, a few slate points were found. Bones of trout (Salmo trutta).

\section{T-1001. Hein $33 / 3$}

$5020 \pm 100$

Charcoal from depth .35 to $.40 \mathrm{~m}$, Level III. Comment (SI): dates $(\mathrm{T}-1005,-1001)$ indicate that tanged points were used in this area at the transition between Mesolithic and Younger Stone age. This is earlier than type appearance in the "Pit-ware-culture" in S Scandinavia.

\section{T-1076. Hein 33/4}

$4920 \pm 90$

2970 BC

Elk bone (Alces alces) from depth $.45 \mathrm{~m}$, Level IV. Trout bones (Salmo trutta) also found. Comment (SI): date agrees with T-1001 and T-1005. Level IV revealed no slate; it was probably introduced later. Dates indicate that tanged-point tradition existed unbroken from Mesolithic time to Younger Stone age in $\mathrm{mt}$ areas of S Norway.

T-1004. Hein 33/5

$4240 \pm 130$

$2290 \mathrm{BC}$

Charcoal from depth $.15 \mathrm{~m}$ in fire pit. Comment (SI): dates youngest settlement phase.

T-1002. Hein $33 / 6$

$4190 \pm 110$

2240 вс

Charcoal from cultural layer in outer part of site, depth $.45 \mathrm{~m}$.

T-1398. Nordmannslågen $\mathbf{7 2 4}$

$7420 \pm 330$

$\mathbf{5 4 7 0}$ вC

Charcoal from depth $.20 \mathrm{~m}$ in fire pit in small site at $+1250 \mathrm{~m}$ near

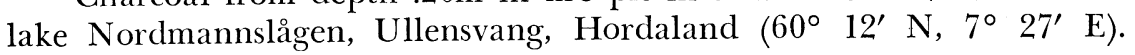


Comment (SI): quartz artifacts and very few tools were found, as in sites Hein 85 and 76 . Finds look very homogeneous and dates agree well.

\section{T-1234. Nordmannslågen $512 / 1$}

$5800 \pm 600$

Charcoal from deepest part of cultural layer in site at $+1245 \mathrm{~m}$ at Sandhaug near lake Nordmannslågen, Ullensvang, Hordaland $\left(60^{\circ} 11^{\prime} \mathrm{N}\right.$, $7^{\circ} 29^{\prime} \mathrm{E}$ ). Depth $.35 \mathrm{~m}$. Comment (SI): date agrees well with oldest levels of Hein 33, where artifacts of same character were found.

\section{T-1233. Nordmannslågen $\mathbf{5 1 2 / 2}$}

Charcoal from top layers, depth $.10 \mathrm{~m}$. Comment (SI): date too young, as artifacts of Mesolithic character were found at depth .01 to $.02 \mathrm{~m}$. Discrepancy might be explained by frost stirring.

\section{T-1230. Nordmannslågen $550 / 1$}

$3250 \pm 150$

Charcoal from depth $.15 \mathrm{~m}$ in fireplace in center of 1 of 2 circular housegrounds at $+1255 \mathrm{~m}$ at Sandhaug. All artifacts made of flint, quartz, and quartzite.

\section{T-1231. Nordmannslågen $550 / 2$}

Charcoal from depth .08 to $.10 \mathrm{~m}$ in fire pit outside housegrounds.

T-1229. Nordmannslågen $\mathbf{5 5 0 / 3}$

Charcoal from depth .06 to $.08 \mathrm{~m}$ in fireplace in center of the youngest looking houseground. Comment (SI): dates from Loc 550 indicate that stone was used as raw material in Bronze age period in this area; agrees with dates from rock shelters and caves with similar artifacts, indicating late stone technology in $\mathrm{mt}$ areas of $\mathrm{S}$ Norway.

\section{T-1236. Nordmannslågen $\mathbf{5 4 7}$}

$3010 \pm 160$

Charcoal from depth $.10 \mathrm{~m}$ in fireplace in center of another circular houseground at $+1255 \mathrm{~m}$ at Sandhaug. Comment (SI): date agrees with dates from Loc 550.

\section{T-1394. Skryken 1113}

From charcoal concentration $.20 \mathrm{~m}$ below surface at $+1158 \mathrm{~m}$ at Skryken, Nore og Uvdal, Buskerud $\left(60^{\circ} 15^{\prime} \mathrm{N}, 8^{\circ} 04^{\prime} \mathrm{E}\right)$. Comment (SI): artifacts of Mesolithic character, few tools. Microblades are frequent.

\section{T-1397. Töddölvatn 1100}

Charcoal from depth $.30 \mathrm{~m}$ in hearth in cultural layer at $+1105 \mathrm{~m}$ at Töddölvatn, Nore og Uvdal, Buskerud $\left(60^{\circ} 19^{\prime} \mathrm{N}, 8^{\circ} 17^{\prime} \mathrm{E}\right)$. Comment (SI): site not dateable by artifacts. 
T-1449. Veivatn $618 / 1$

$4290 \pm 170$

Charcoal from depth .15 to $.18 \mathrm{~m}$ in hearth in artifact-bearing cultural layer of Stone age site at $+1178 \mathrm{~m}$ at Veivatn, Ullensvang, Hordaland $\left(60^{\circ} 15^{\prime} \mathrm{N}, 6^{\circ} 55^{\prime}\right.$ E Long).

T-1396. Veivatn 618/2

$4080 \pm 140$

Charcoal from depth $.10 \mathrm{~m}$ in hearth.

2130 BC

T-1395. Veivatn 634

$4200 \pm 170$

2250 BC

Charcoal from depth .10 to $.12 \mathrm{~m}$ in hearth of Stone age site at $+1180 \mathrm{~m}$ at Veivatn.

\section{Laerdal series}

Charcoal from site with clearly defined Stone age technique at $+1315 \mathrm{~m}$ in Kjöleskarvet S, near lake Store Öljusjö, Laerdal, Sogn og Fjordane $\left(60^{\circ} 58^{\prime} \mathrm{N}, 8^{\circ} 04^{\prime} \mathrm{E}\right)$. Artifacts made of quartzite. Coll and subm 1971 by Arne Johansen, Hist Mus, Univ Bergen. Comment (AJ): dates give surprisingly low age for site with Mesolithic stone working technique (Johansen, 1969; Vorren, 1973).

\section{T-1186. Kjöleskarvet 1}

$2450 \pm 160$

From charcoal layer at depth .15 to $.18 \mathrm{~m}$. Circular layer of brittleburnt stones at depth .10 to $.15 \mathrm{~m}$; many artifacts in top layer.

\section{T-1243. Kjöleskarvet 2}

$3520 \pm 300$

From depth $.15 \mathrm{~m}$, beneath stone layer of exactly same type.

\section{Storbåthallaren series}

Charcoal and shell from cave at $+7.5 \mathrm{~m}$ with kitchen midden deposits at Storbåthallaren, Moskenes, Nordland $\left(68^{\circ} 05^{\prime} \mathrm{N}, 13^{\circ} 25^{\prime} \mathrm{E}\right)$. Thick layers of shell and fish bones, mostly from big cod (skrei), but also from many species of mammals and birds. Bone and slate artifacts showing hunting and fishing economy. Two Younger Stone age phases, separated by last Tapes transgression. Coll and subm 1970 and 1971 by Astrid Utne, Tromsö Mus, Univ Tromsö (Utne, 197la, b).

\section{T-1200. Storbåthallaren 1}

$2060 \pm 80$

Charcoal from depth $.18 \mathrm{~m}$.

\section{T-1013. Storbåthallaren 2}

$2330 \pm 110$

Charcoal from depth $.25 \mathrm{~m}$. Comment (AU): latest phase of Younger Stone age settlement, agrees with archaeol dating.

\section{T-1198. Storbåthallaren 3}

$4740 \pm 140$

Charcoal from depth $.30 \mathrm{~m}$. 
T-1017. Storbåthallaren 4

$4910 \pm 80$

Mollusks from depth $.40 \mathrm{~m}$ to $.50 \mathrm{~m}$.

2960 вC

T-1014. Storbåthallaren 5

$5250 \pm 80$

Charcoal from depth $.50 \mathrm{~m}$.

3300 BC

T-1016. Storbåthallaren 6

$2460 \pm 70$

Charcoal from depth $.55 \mathrm{~m}$. Comment (AU): date too young, but further excavation showed stratigraphy was disturbed.

\section{T-1018. Storbåthallaren 7}

$5080 \pm 90$

Mollusks from depth .60 to $.70 \mathrm{~m}$.

3130 BC

\section{T-1015. Storbåthallaren 8}

$4000 \pm 800$

Coal from depth $.70 \mathrm{~m}$. Lab comment: sample extremely undersized, $8 \%$ sample gas $(. \operatorname{lgC})$. Date might be too young.

\section{Devdisvatn series}

Charcoal and charred bones from fireplace and shallow pits assoc with Mesolithic/Younger Stone age artifacts at $+412 \mathrm{~m}$ at lake Devdisvatn, Målselv, Troms $\left(69^{\circ} 47^{\prime} \mathrm{N}, 19^{\circ} 40^{\prime} \mathrm{E}\right)$. Coll 1970 and subm 1972 by Knut Helskog, Tromsö Mus, Univ Tromsö. Comment (KH): bone dates both considerably younger than indicated by cultural inventory. T-1343 corresponds with archaeol date.

\section{T-1342. Devdisvatn 1}

$1020 \pm 180$

Charred bone from depth .05 to $.10 \mathrm{~m}$ in pit.

AD 930

\section{T-1453. Devdisvatn 2}

$1800 \pm 220$

Charred bone from depth .05 to $.07 \mathrm{~m}$ in pit.

\section{T-1343. Devdisvatn 3}

$6570 \pm 150$

Charcoal from depth .10 to $.15 \mathrm{~m}$ in fireplace.

\section{Stegaros series, Hardangervidda}

Charcoal from cultural layers assoc with rock shelters in Stegaros, Tinn, Telemark $\left(60^{\circ} 05^{\prime} \mathrm{N}, 8^{\circ} 17^{\prime} \mathrm{E}\right)$. Stegaros, at lake Mår on Hardangervidda, is site with 2 rock shelters, several housegrounds, and pits with charcoal and heated stones. Coll 1972 by Lil Gustafson and Svein Indrelid; subm 1972 by Lil Gustafson, Univ Oldsaksamling, Oslo. Comment (LG): rock shelters were used in Late Neolithic, Bronze age, Iron age, and occasionally later. 
T-1445. Stegaros 1058/1

$3810 \pm 90$

From depth $.68 \mathrm{~m}$ in cultural layer .70 to $.80 \mathrm{~m}$ thick in rock shelter, Loc 1058. Fragmented animal bones and heated stones; all artifacts in lower parts were of flint and quartzite, eg, flat-chopped arrowheads.

T-1452. Stegaros 1058/2

AD 1350

$600 \pm 120$

From depth $.30 \mathrm{~m}$ in fireplace in rock shelter. Flint and quartzite.

\section{T-1450. Stegaros 1006/1}

$2980 \pm 170$

From depth $.60 \mathrm{~m}$ in refuse heap outside rock shelter Loc 1006. Artifacts of stone and iron: flat-chopped tools of flint and quartzite, nails, fish hooks and other iron items, as well as fragmented animal bones and heated stones.

\section{T-1451. Stegaros 1006/2}

AD 1350

$600 \pm 120$

From fireplace in base of cultural layer $.20 \mathrm{~m}$ thick inside rock shelter. Comment (LG): fireplace belongs to late settlement, stratigraphy shows that oldest cultural accumulations were discarded. Artifacts, mostly iron nails and strike-a-lights of flint, do not contradict date.

\section{Gjerland series}

Charcoal from 4 out of nearly 50 fireplaces assoc with 2 rare housegrounds on a terrace at $+300 \mathrm{~m}$ in Gjerland, Förde, Sogn og Fjordane $\left(61^{\circ} 25^{\prime} \mathrm{N}, 6^{\circ} 25^{\prime} \mathrm{E}\right)$. Coll 1971 and 1972; subm 1972 and 1973 by Björn Myhre, Hist Mus, Univ Bergen. Comment (BM): archaeol material very scanty and difficult to date. Structures were supposedly from Early Iron age, probably Migration period; agreeing with dates (Myhre, 1973a).

\section{T-1334. Gjerland 1}

From depth $.25 \mathrm{~m}$ inside House I.

\section{T-1404. Gjerland 2}

From depth $.20 \mathrm{~m}$ in another fireplace in House I.

\section{T-1459. Gjerland 3}

From depth $.25 \mathrm{~m}$ in House II.

\section{T-1335. Gjerland 4}

$1790 \pm 110$ AD 160

$$
\begin{array}{r}
1650 \\
\text { AD } 300
\end{array}
$$

$1670 \pm 80$ AD 280

$$
1580 \pm 150
$$

AD 370

From depth $.50 \mathrm{~m}$ in fireplace outside the housegrounds.

\section{Boat house series, Stend}

Charcoal from fireplaces and wood from walls of boat house from Early Iron age at $+3 \mathrm{~m}$ in Stend, Bergen, Hordaland $\left(60^{\circ} 15^{\prime} \mathrm{N}, 5^{\circ} 20^{\prime} \mathrm{E}\right)$. Coll and subm 1970 to 1972 by B Myhre. Comment (BM): house was ca 
$32 \mathrm{~m} \times 5 \mathrm{~m}$, dated archaeologically by earliest pottery to $1600 \mathrm{BP}$. Walls might be older than oldest artifacts (Myhre, 1973b).

\section{T-1067. Stend 1}

$1730 \pm 160$

From end wall, depth $.50 \mathrm{~m}$.

\section{T-1241. Stend 2}

From end wall, depth $.50 \mathrm{~m}$.

\section{T-1336. Stend 3}

From W side wall, depth $.50 \mathrm{~m}$.

\section{T-1337. Stend 4}

From depth $.50 \mathrm{~m}$ in fireplace at entrance.

\section{T-1242. Stend 5}

$$
1810 \pm 60
$$

From depth $.75 \mathrm{~m}$ in fireplace.

$$
\begin{array}{r}
1790 \pm 110 \\
\text { AD } 160
\end{array}
$$

$1520 \pm 70$

$$
1680 \pm 60
$$

AD 270

\section{Lonelega rock shelter series}

Charcoal from cultural layers in the rock shelter Lonelega $\mathrm{I}$ at $+835 \mathrm{~m}$ at Lake Lonevatn, Forsand, Rogaland ( $\left.59^{\circ} 10^{\prime} \mathrm{N}, 6^{\circ} 55^{\prime} \mathrm{E}\right)$. Dates different stages of visits or settlements during Later Bronze age, PreRoman Iron age, and Medieval age. Two 1st stages are represented by different types of flat-chopped arrowheads and potsherds. Finds from Stone age and Migration period in other layers. Coll 1972 by Birgitta Broberg; subm 1972 by Egil Mikkelsen, Univ Oldsaksamling, Oslo.

\section{T-1426. Lonelega I/1}

From fireplace in Layer 3.

\section{T-1428. Lonelega I/2}

From Layer 6.

\section{T-1427. Lonelega I/3}

From Layers 7 and 8.

$$
\begin{gathered}
590 \pm 200 \\
\text { AD } 1360 \\
\\
2320 \pm 150 \\
370 \text { BC } \\
2780 \pm 110 \\
830 \text { BC }
\end{gathered}
$$

\section{Risöya series, Sund}

Charcoal from 1 excavated houseground of 8, situated around a shallow bay facing $\mathrm{E}$ on treeless, uninhabited Risöya I., outside Toft in Sund, Hordaland $\left(60^{\circ} 10^{\prime} \mathrm{N}, 5^{\circ} \mathrm{E}\right)$. Four cooking pits inside houseground, with central fireplace. Finds are mainly iron fishing hooks and knives, soapstone sinkers, cooking pots, and whetstones. Coll and subm 1972 by Bente Magnus Myhre, Hist Mus, Univ Bergen. Comment (BMM): habitation assumed to be seasonal fishing communities during Late Iron age, confirmed by dates. T-1406 slightly too old, might be caused by use of driftwood. 
T-1405. Risöya 1

$1150 \pm 90$

From depth $.10 \mathrm{~m}$ in top layer of cooking pit near $\mathrm{W}$ wall.

T-1461. Risöya 2

$1370 \pm 160$

Charred branch from depth $.30 \mathrm{~m}$ in cooking pit. AD 580

T-1460. Risöya 3

$1230 \pm 60$

AD 720

Remnants of burnt plank from wall or floor, from depth $.40 \mathrm{~m}$ partly under $\mathrm{W}$ foundation wall.

\section{T-1406. Risöya 4}

$1630 \pm 110$

From depth $.40 \mathrm{~m}$ in bottom layer of fireplace.

AD 320

\section{Lille Gautelis series, Ankenes}

Charcoal from different fireplaces in site at $+856 \mathrm{~m}$ in Lille Gautelis, Ankenes, Nordland $\left(68^{\circ} 01^{\prime} \mathrm{N}, 17^{\circ} 50^{\prime} \mathrm{E}\right)$. Coll 1971 and subm 1972 by Knut Helskog, Tromsö Mus, Univ Tromsö. Comment (KH): archaeol dating based on artifacts in site is very difficult.

T-1252. L Gautelis 1

AD 1370

From depth .05 to $.08 \mathrm{~m}$.

AD 1470

T-1253. L Gautelis 2

From depth .04 to $.08 \mathrm{~m}$.

$6130 \pm 170$

T-1344. L Gautelis 3

4180 BC

From depth .04 to $.08 \mathrm{~m}$ outside fireplace dated by T-1253.

T-1345. L Gautelis 4

AD 1630

From depth .04 to $.10 \mathrm{~m}$.

2. Cemeteries and burial mounds

\section{Gunnarstorp series, Östfold}

Charcoal from Early Iron age cemetery with $>150$ flat graves covered by a flat stone or various kinds of stone pavements at $+35 \mathrm{~m}$ in Gunnarstorp, Skjeberg, Östfold $\left(59^{\circ} 12^{\prime} \mathrm{N}, 11^{\circ} 8^{\prime} \mathrm{E}\right)$. Coll 1955 to 1959 by Univ Oldsaksamling, Oslo; subm 1971 and 1972 by Trond Löken, Univ Oldsaksamling.

\section{T-1212. Grave 31}

$2070 \pm 80$

From depth .20 to $.60 \mathrm{~m}$ in pit fire covered with flat stone, containing burnt bones and potsherds. Cremation grave marked on surface with round stone pavement, diam $6 \mathrm{~m}$. 


\section{T-1213. Grave 159}

From depth $.35 \mathrm{~m}$ in pit fire covered with a stone. Cremation grave asymmetrically surrounded by circular row of stones, diam $2.25 \mathrm{~m}$. In center small stone pavement connected to stone circle by 2 radial rows of stones.

\section{T-1292. Grave 37}

$270 \pm 70$

From $.10 \mathrm{~m}$ thick charcoal layer at depth $.10 \mathrm{~m}$ from center of stone circle, diam $8 \mathrm{~m}$, including 11 standing stones connected with stone pavement. Comment (TL): sample obviously recent compared to stone circle.

\section{T-1293. Grave 3}

$2050 \pm 70$

From charcoal layer at depth $.50 \mathrm{~m}$ at base of round grave mound, of gravel and stones and surrounded by a kerb. Potsherds and burnt bones were in layer.

\section{T-1294. Grave 40}

$380 \pm 60$

From charcoal layer at depth .10 to $.20 \mathrm{~m}$ with a few burnt bones, covered by irregular stone pavement. Comment (TL): date does not agree with supposed age.

\section{T-1295. Grave 70}

$2970 \pm 70$ 1020 BC

From depth $.35 \mathrm{~m}$ in pit with burnt stones, fragments of iron and potsherds, covered wth 2 flat stones and surrounded by triangular stone pavement with kerb. Comment (TL): date older than expected.

\section{T-1296. Grave 54}

$2350 \pm 80$ $400 \mathrm{BC}$

From depth .20 to $.50 \mathrm{~m}$ in pit with burnt bones, covered by flat stone.

\section{T-1297. Grave 52}

$2230 \pm 80$

From pit with bronze needle and burnt bones, covered with flat stone and surrounded by elliptical stone pavement with a kerb.

\section{T-1440. Grave 52}

$$
2230 \pm 60
$$

From another pit inside same pavement.

$$
280 \text { BC }
$$

\section{T-1439. Grave 41}

$$
1020 \pm 70
$$

From pit containing soil mixed with charcoal, covered with irregular stone pavement, diam $3 \mathrm{~m}$. Comment (TL): pavement probably recent compared to cemetery. 
T-1441. Grave 75

$$
330 \pm 100
$$

From heap of potsherds mixed with burnt bones and small quantities of charcoal in stone cist, covered with an irregular kerb, diam $1.40 \mathrm{~m}$. Comment (TL): charcoal must be recent compared to potsherds and bones.

\section{St Clemens church series, Oslo}

Human bone and wood from oldest graves in 2 cemeteries at $+10 \mathrm{~m}$, from excavation of St Clemens church, Gamlebyen, Oslo $\left(59^{\circ} 54^{\prime} \mathrm{N}, 10^{\circ}\right.$ $46^{\prime}$ E). Probably oldest Christian cemeteries in Norway known; supposedly from early 12th century. Coll and subm 1971 by The Central Office Hist Monuments, Archaeol Sec, Oslo. Comment (COHM): dates slightly older than expected. T-1327 and -1328 are from oldest graves.

T-1156. St Clemens church, 133T

Stick of wood from depth $1.9 \mathrm{~m}$.

T-1210. St Clemens church, 136B

Human bones from depth $2 \mathrm{~m}$.

T-1325. St Clemens church, 136T

Plank from coffin containing skeleton dated by T-1210.

T-1326. St Clemens church, 137B

Human bones from depth $2 \mathrm{~m}$.

T-1327. St Clemens church, 145B

Human bones from depth $2.1 \mathrm{~m}$.

T-1328. St Clemens church, 146B

Human bones from depth $2.2 \mathrm{~m}$.
$890 \pm 150$ AD 1060

$$
\begin{array}{r}
990 \\
\text { AD } 960
\end{array}
$$

$1040 \pm 110$ AD 910

\section{Lille Sölensjöen series}

Charcoal from concentrations in burial cairns at $+700 \mathrm{~m}$ at lake Lille Sölensjöen, Övre Rendal, Hedmark $\left(62^{\circ} 02^{\prime} \mathrm{N}, 11^{\circ} 37^{\prime} \mathrm{E}\right)$. Coll and subm 1971 to 1973 by Arne Skjölsvold, Univ Oldsaksamling, Oslo. Comment (AS): part of study on Iron age settlements in $\mathrm{mt}$ regions in SE Norway. Dates T-1178 and -1179 too old; probably use of old fire wood.

T-1178. Lille Sölensjöen I

From depth $.30 \mathrm{~m}$.

T-1179. Lille Sölensjöen II

From depth $.20 \mathrm{~m}$.
$4080 \pm 170$ 3090 BC

$2430 \pm 60$ $480 \mathrm{BC}$ 
T-1430. Lille Sölensjöen, Grav V

$$
1580 \pm 80
$$

From charcoal concentration assoc with plane-iron and mounting of sword scabbard.

\section{T-1041. Bringsjord, Lyngdal}

Charcoal from concentration at depth $.50 \mathrm{~m}$ in burial mound at $+30 \mathrm{~m}$

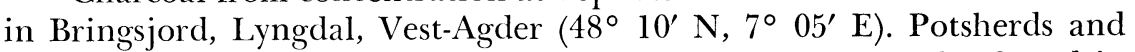
burnt bones underlying charcoal layer; flat piece of bronze also found in mound. Coll and subm 1970 by Trond Löken, Univ Oldsaksamling, Oslo. Comment (TL): date older than expected, finds do not contradict date.

\section{Steinhaug series, Saerheim}

Charcoal from pits underneath outer parts of a Bronze age mound at $+70 \mathrm{~m}$ in Saerheim, Klepp, Rogaland $\left(58^{\circ} 46^{\prime} \mathrm{N}, 5^{\circ} 17^{\prime} \mathrm{E}\right)$. Samples from middle of 5 different pits, $.50 \mathrm{~m}$ deep, filled with charcoal and earth. Coll 1970 by Reidar Bertelsen, Stavanger Mus; subm 1971 by Oddmund Möllerop, Stavanger Mus, Stavanger. Comment (OM): outer part of mound younger than lower central, probably contemporary with a secondary burial in Roman period (Bertelsen, 1970).

\section{T-991. Saerheim 1}

$$
\begin{aligned}
& 2340 \pm 70 \\
& 390 \text { BC }
\end{aligned}
$$

T.992. Saerheim 2

$$
2460 \pm 70
$$

510 BC

\section{T-1201. Saerheim 3}

$$
2470 \pm 80
$$

520 BC

\section{T-1314. Saerheim 4}

$$
2610 \pm 80
$$
$660 \mathrm{BC}$

\section{T-1315. Saerheim 5}

\section{Sörheim series, Etne}

Charcoal from different barrows and graves in big cemetery at $+50 \mathrm{~m}$ in Sörheim, Etne, Hordaland (59 $\left.40^{\prime} \mathrm{N}, 6^{\circ} \mathrm{E}\right)$. Coll 1969 by Svein Indrelid and Anne Zachariassen, Hist Mus, Univ Bergen; subm 1971 by Björn Myhre (1972).

\section{T-1278. Barrow $5 / 18$}

$2940 \pm 130$

From charcoal layer at base of big barrow, depth $1 \mathrm{~m}$. Comment (BM): date as expected, correlates well with previous dates from Bronze age barrow at other end of cemetery ( $R, 1972, \mathrm{v} 14, \mathrm{p} 444)$.

\section{T-1280. Fireplace $5 / 18$}

From fireplace at depth $1.30 \mathrm{~m}$ below layer of earth underlying char- 
coal layer dated by T-1278. Comment (BM): Late Stone age or Early Bronze age is reasonable.

\section{T-1279. Grave 5/13}

$1230 \pm 70$

From grave pit at base of barrow. Comment (BM): date correlates well with type of grave and poor grave goods from pit.

\section{T-1065. Gjerstad}

$1780 \pm 80$

Charcoal from a cremation grave at depth $3 \mathrm{~m}$ in center of big barrow at $+100 \mathrm{~m}$ in Gjerstad, Voss, Hordaland $\left(60^{\circ} 40^{\prime} \mathrm{N}, 6^{\circ} 20^{\prime} \mathrm{E}\right)$. Coll 1968 by Bente Magnus Myhre; subm 1970 by Björn Myhre. Comment (BM): date too old, archaeol date AD $400 \mathrm{yr}$.

\section{Charcoal pit series}

Charcoal from small pits with charcoal, stones, and few or no remains of burnt bones, a phenomenon often observed in Iron age cemeteries. The fact that the pits often are found in the bottom of barrows, seems incidental. They nearly always are older than barrows, probably representing a very extreme kind of burial rite in Early Iron age. Coll 1966 to 1971 and subm 1970 to 1972 by Oddmunn Farbregd, DKNVS Mus, Univ Trondheim (Farbregd, 1971, 1972a, b).

\section{T-987. Kvello, Pit A}

$2020 \pm 90$

From pit in bottom of barrow at $+160 \mathrm{~m}$ in Kvello, Verdal, NordTröndelag $\left(63^{\circ} 46^{\prime} \mathrm{N}, 11^{\circ} 41^{\prime} \mathrm{E}\right)$. Cist burial in center of barrow $(25 \mathrm{~m}$ wide $\times 3 \mathrm{~m}$ high) dated at AD 350 to 450 .

\section{T-1120. Kvello, Pit B}

$$
1950 \pm 80
$$

From pit $.50 \mathrm{~m}$ from Pit A, same level.

\section{T-1121. Kvello, Pit C}

From pit $.80 \mathrm{~m}$ from Pit B, same level. Comment (OF): dates confirm pits are older than cist burial.

\section{T-1122. Kvello, Trench}

$1680 \pm 70$ AD 270

From trench in bottom of same barrow. Trench is part of circle with central stone cist, marking periphery of a small primary barrow. Comment $(\mathrm{OF})$ : trench probably contemporary with cist burial; date not conclusive.

\section{T-1125. Vie, pit under long barrow}

Sample from oval pit at base of barrow $20 \mathrm{~m}$ long at $+\mathrm{ca} 100 \mathrm{~m}$ in Vie, Grong, Nord-Tröndelag ( $\left.64^{\circ} 29^{\prime} \mathrm{N}, 12^{\circ} 10^{\prime} \mathrm{E}\right)$. Comment (OF): date confirms pit is older than barrow. 
T-1123. Figga, pit in boat grave

$1470 \pm 80$

AD 480

From pit at base of round barrow, ca $11 \mathrm{~m}$ wide at $+10 \mathrm{~m}$ in Figga, Steinkjer, Nord-Tröndelag $\left(64^{\circ} 01^{\prime} \mathrm{N}, 11^{\circ} 29^{\prime} \mathrm{E}\right)$, containing boat burial of late Viking period. Comment (OF): pit is clearly older than barrow.

\section{T-1124. Vang, Barrow 587, pit}

$1430 \pm 90$

From pit at base of round barrow, $5 \mathrm{~m}$ wide at $+575 \mathrm{~m}$ in Vang, Oppdal, Sör-Tröndelag $\left(62^{\circ} 36^{\prime} \mathrm{N}, 9^{\circ} 39^{\prime} \mathrm{E}\right)$. No burnt bones, iron arrow head typical of Merovingian period on top of pit. Comment (OF): pit assumed to represent burial over which barrow was built; date agrees.

\section{T-1287. Hollingen, pit}

$$
\begin{gathered}
2320 \pm 70 \\
370 \mathrm{BC}
\end{gathered}
$$

From pit at ca $+40 \mathrm{~m}$ just outside stone cist from Migration period in Hollingen, Aukra, Möre og Romsdal ( $\left.62^{\circ} 47^{\prime} \mathrm{N}, 6^{\circ} 58^{\prime} \mathrm{E}\right)$. Comment $(\mathrm{OF})$ : pit clearly older than cist burial.

\section{T.988. Å, Barrow 8, pit}

$1670 \pm 70$

From pit at base of Viking period barrow at $+15 \mathrm{~m}$ in $\AA$, Snillfjord, Sör-Tröndelag $\left(63^{\circ} 24^{\prime} \mathrm{N}, 9^{\circ} 30^{\prime} \mathrm{E}\right)$.

\section{T.990. Å, separate pit}

$1860 \pm 90$

From pit $6 \mathrm{~m}$ outside barrow covering pit dated by T-988. Comment (OF): both pits clearly older than barrow.

\section{Å cemetery series}

Charcoal samples related to primary and secondary stages of grave monument at $+15 \mathrm{~m}$ in $\AA$, Snillfjord, Sör-Tröndelag $\left(63^{\circ} 24^{\prime} \mathrm{N}, 9^{\circ} 30^{\prime} \mathrm{E}\right)$. Coll 1970 and subm 1970 and 1972 by O Farbregd (1971, 1972a, b).

\section{T-989. Å, Barrow 8, stone cist}

Pieces of charcoal scattered in original surface under stone cist centrally situated in cairn $6 \mathrm{~m}$ wide. In secondary stage of use covered by larger earth mound. Comment (OF): date is post quem, probably direct, $i e$, cist can be Bronze or Early Iron age.

\section{T-1288. Å, Barrow 8, trench}

$1240 \pm 70$

From charcoal concentration at base of trench around barrow. Comment (OF): sample most probably contemporary with trench and barrow; date confirms secondary use of monument in Viking period.

\section{Lappish Iron age series, Finnmark}

Birch-bark from graves in rock-strewn slopes used as burial sites. Most samples from Mortensnes, Nesseby, Finnmark $\left(70^{\circ} 07^{\prime} \mathrm{N}, 29^{\circ} 20^{\prime} \mathrm{E}\right)$. 
Also charcoal and bone from house site at Mortensnes including several housegrounds belonging to same cultural tradition. Coll 1967 to 1970 and subm 1968 to 1970 by Else Johansen Kleppe, Hist Mus, Bergen. T-674 coll 1967, T-673 and -674 subm 1968 by Knut Odner, Hist Mus, Bergen. Comment $(\mathrm{EJK})$ : series indicate that Lappish Iron age lasted from approx AD 1 to AD 1700 (Solberg, 1909; Johansen and Odner, 1968).

\section{T-871. Mortensnes 1, Grave 39}

Birch-bark, mostly decorated, from flagstone coffin in Mortensnes burial site. Other finds: 6 quartzite scrapers, 2 flakes, 1 pumice stone with flat polished surface, and skeletal remains. Depth $.5 \mathrm{~m}$.

T-872. Mortensnes 2, Grave 145

$300 \pm 50$

Birch-bark from partly opened and collapsed flagstone coffin. Other finds: 3 bronze needles, 1 pearl, 2 spindle whirls, 3 quartzite flakes, 2 pumice stones with flat polished surfaces and skeletal remains. Depth ca $.7 \mathrm{~m}$.

T-874. Mortensnes 3, Grave 97

$1000 \pm 70$ AD 950

Birch-bark from flagstone coffin, previously unopened. Other finds: quartzite scrapers and flakes, skeletal remains. Depth .5m.

T-933. Mortensnes 4, Grave 10

$1460 \pm 90$ AD 490

Birch-bark from previously opened flagstone coffin. No other finds. Depth ca $.6 \mathrm{~m}$.

T-934. Mortensnes 5, Grave 65

$250 \pm 90$

Birch-bark from previously opened flagstone coffin. Other finds: 3 pumice stones. Depth .5m.

T-935. Mortensnes 6, Grave 113

$$
300 \pm 90
$$

Birch-bark from previously unopened but collapsed coffin. Depth ca $.2 \mathrm{~m}$. Other finds: quartzite scrapers and flakes and 1 skeleton.

T-673. Mortensnes 7, House 26, Sec A

$600 \pm 70$

Charcoal from depth ca $.25 \mathrm{~m}$ in fireplace, Houseground 26, Sec A.

T-870. Mortensnes 8, House 26, Sec A

$\leqslant 100$

Bones of domestic animals from depth ca $.15 \mathrm{~m}$ in cultural layer with other animal bones and artifacts, some recent. No stratification observed.

T-675. Mortensnes 9, Sec A

$$
2420 \pm 120
$$

Charcoal from depth ca $.15 \mathrm{~m}$ in concentration of stones in Sec A. 
T-674. Mortensnes 10, House 10, Sec B

Charcoal from layer at depth ca $.25 \mathrm{~m}$, under fireplace.

\section{T.873. Kariel, Grave I}

Birch-bark from previously unopened flagstone coffin in Kariel, Vadsö, Finnmark $\left(70^{\circ} 06^{\prime} \mathrm{N}, 29^{\circ} 23^{\prime} \mathrm{E}\right)$. Most bark was decorated; skeletal remains also found. Depth $.4 \mathrm{~m}$.

\section{T-1053. Skalnes grave}

$$
200 \pm 70
$$

Birch-bark from unopened flagstone coffin in Skalnes, Vadsö, Finnmark $\left(70^{\circ} 13^{\prime} \mathrm{N}, 30^{\circ} 29^{\prime} \mathrm{E}\right)$. Other finds: bronze pendant, penannular bronze brooch, and skeletal remains. Depth $.5 \mathrm{~m}$. Comment (EJK): date younger than burial. Archaeol date, based on well dated imported wares: AD 1000 to AD 1100.

\section{Bog iron industries}

\section{Mösstrand series, Telemark}

Charcoal from iron extraction sites in $\mathrm{mt}$ community Mösstrand, Vinje, Telemark $\left(59^{\circ} 50^{\prime} \mathrm{N}, 8^{\circ} 10^{\prime} \mathrm{E}\right)$. Dateable objects are few, series establishes chronology for sites and furnace types, ranging from AD 500 to 1350. Sites differ widely in character and size. Skarbjåen samples coll 1970 by Anne S Alsvik, T-1182 and -1183 in 1971 by Per Kr Horn, all others by Irmelin Martens 1961 to 1972; subm 1970 to 1972 by I Martens, Univ Oldsaksamling, Oslo (Martens, 1972).

T-1068. Skarbjåen $30 / 52$ no. $3 / 1$

$1200 \pm 80$

From original surface under slag heap assoc with house site at $+975 \mathrm{~m}$ (Loc 3) in Skarbjåen.

T-1069. Skarbjåen $30 / 52$ no. $3 / 2$

$975 \pm 80$

From slag groove at $\mathrm{E}$ side of bottom flagstone of furnace.

T-1073. Skarbjåen $30 / 52$ no. $7 / 1$

$970 \pm 80$

AD 980

From original surface under separate slag heap (Loc 7).

T-1074. Skarbjåen $30 / 52$ no. $7 / 2$

$780 \pm 110$

From $\mathrm{S}$ slag groove, close to the furnace in Loc 7 .

T-1072. Homvassbekken $30 / 52$ no. 5/1

\section{AD 1170}

$$
920 \pm 70
$$

AD 1030

From original surface under slag heap assoc with house site and 2 furnaces (Loc 5), at $+950 \mathrm{~m}$ at Homvassbekken. 
T-1071. Homvassbekken $30 / 52$ no. $5 / 2$

$910 \pm 70$

Coll near W rim of Furnace I, covered with earth mixed with charcoal and slag.

T-1070. Homvassbekken $30 / 52$ no. $5 / 3$ AD 1070

$880 \pm 70$

Coll under a big lump of slag, clotted in bottom of Furnace II.

T-1109. Mogen

$720 \pm 80$

From original surface layer close to furnace assoc with house site at $+920 \mathrm{~m}$ in Mogen. Comment (IM): a few objects of Viking or Medieval age were found; date agrees well.

T-1110. Varland $33 / 49$ no. 4 $1200 \pm 80$

Coll just outside furnace at $+915 \mathrm{~m}$ in Varland.

AD 750

T-1111. Martinvika $30 / 52$ no. 6

$$
1190 \pm 150
$$

AD 760

From small pit assoc with slag heap and furnace at $+950 \mathrm{~m}$ near Martinvika. Comment (IM): furnace is very similar to $33 / 49$ no. 4 (T$1110)$.

T-1443. Martinvika 30/52 no. 1

$$
\begin{array}{r}
970 \pm 70 \\
\text { AD } 980
\end{array}
$$

From original surface under slag heap assoc with house site at $+950 \mathrm{~m}$ in Martinvika. Comment (IM): site dated previously to $960 \pm$ 60 вр (T-698, R 1970, v 12, р 235).

T-1181. Erlandsgard 32/56 no. 2/1

$1090 \pm 70$

From original surface underneath large slag heap assoc with 3 furnaces (Loc 2) at $+925 \mathrm{~m}$ in Erlandsgard.

T-1320. Erlandsgard 32/56 no. $2 / 2$

$1480 \pm 70$ AD 470

From original surface under slag heap. Comment (IM): date too old, T-1180 and -1181 from same site both give Viking period.

T-1180. Erlandsgard 32/56 no. 2/3

$960 \pm 90$

From Furnace I. AD 990

T-1183. Erlandsgard $32 / 56$ no. $3 / 1$ (Loc 3).

From original surface under large slag heap assoc with 4 furnaces

T-1182. Erlandsgard $32 / 56$ no. $3 / 2$ $980 \pm 110$

From Furnace IV. Comment (IM): the few objects dated to Viking age/early Medieval, agree with dates from site. 
T-1184. Erlandsgard $32 / 56$ no. 5

$1280 \pm 70$

From original surface under slag heap (Loc 5).

T-1321. Erlandsgard 32/56 no. $6 / 1$ AD 670

From original surface under slag heap (Loc 6).

T-1185. Erlandsgard $32 / 56$ no. $6 / 2$

From charcoal mixed soil in furnace.

T-1444. Erlandsgard $32 / 57$ no. 1

$1390 \pm 80$

AD 560

$1410 \pm 150$ AD 540

$1260 \pm 80$

AD 690

From original surface under slag heap assoc with house site at $+925 \mathrm{~m}$ in Erlandsgard.

\section{Hunting constructions and localities}

\section{Reindeer drive series, Hardangervidda}

Charcoal and reindeer bone from lake-side sites characterized by remnants of stone huts in $\mathrm{mt}$ area Hardangervidda. Drift fences consisting of stone cairns are usually found on opposite side of lakes. Hunting method well documented in ethnographic literature: reindeers chased by beaters, diverted into lake by fences, here to be killed by hunters in boat. Coll 1971 and 1972, subm 1972 and 1973 by Otto Blehr and Rolf W Lie, The Hardangervidda project for interdisciplinary cultural research, Bergen. Comment (OB): series dates use of reindeer drive since Late Stone age until Black Death, and regional differences in exploitation of wild reindeer in area by local communities (Blehr, 1973; Negaard, 1911; Böe, 1942).

\section{T-1303. Langevatn 1}

$1890 \pm 110$

Charcoal from depth $.30 \mathrm{~m}$ in fireplace (cooking pit) in distinct remains of stone hut at $+1124 \mathrm{~m}$ at Lake Langevatn, Ullensvang, Hordaland $\left(60^{\circ} 28^{\prime} \mathrm{N}, 7^{\circ} 34^{\prime} \mathrm{E}\right)$. Pit is probably 1 of at least 20 such pits $\mathrm{SW}$ of hut.

T-1228. Langevatn 2

$1740 \pm 110$

Charcoal from depth $.08 \mathrm{~m}, 3 \mathrm{~m}$ outside hut remains. AD 210

T-1251. Langevatn 3a

$1430 \pm 130$

Bone from depth .05 to $.10 \mathrm{~m}$ in bone heap outside stone hut remains.

\section{T-1304. Langevatn 5}

$1600 \pm 110$

Bone from depth $.20 \mathrm{~m}$ in bone heap.

T-1423. Sumtangen 1

AD 1350

$600 \pm 100$

Bone from depth .10 to $.15 \mathrm{~m}$ in bone heap outside remains of stone 
hut at $+1192 \mathrm{~m}$ at lake Finnsbergvatn, Ullensvang, Hordaland $\left(60^{\circ} 29^{\prime} \mathrm{N}\right.$, $\left.7^{\circ} 37^{\prime} \mathrm{E}\right)$. Denoted "East hut" by Negaard (1911).

\section{T-1424. Sumtangen 2}

Bone from bottom layer in bone heap, depth $.50 \mathrm{~m}$.

\section{T-1466. Sumtangen 5}

Bone from cultural layer at depth .10 to $.15 \mathrm{~m}$ outside entrance of another stone hut ("West hut", Negaard, 1911).

\section{T-1514. Sumtangen 10}

Charcoal from bottom layer dated by T-1424.

\section{T-1515. Dragöy 2}

AD 1090

Charcoal from depth .05 to $.10 \mathrm{~m}$ in remains of stone hut at $+1180 \mathrm{~m}$ at Lake Dragöyfjorden, Ullensvang, Hordaland (60 $\left.27^{\prime} \mathrm{N}, 7^{\circ} 41^{\prime} \mathrm{E}\right)$.

\section{T-1306. Dragöy 4}

$840 \pm 130$

Charcoal from depth $.10 \mathrm{~m}$ in remains of another stone hut. Burnt bones and stones also found.

\section{T-1302. Dragöy 5}

$$
\begin{array}{r}
970 \pm 110 \\
\text { AD } 980
\end{array}
$$

Charcoal from depth $.25 \mathrm{~m}$ in remains of 3 rd stone hut. Burnt bones and potsherds.

\section{T-1462. Kraekkja 1a}

Bone from depth $.20 \mathrm{~m}$ in bone heap outside remains of stone hut at $+1153 \mathrm{~m}$ at Lake Storekraekkja, Hol, Buskerud $\left(60^{\circ} 26^{\prime} \mathrm{N}, 7^{\circ} 44^{\prime} \mathrm{E}\right)$.

\section{T-1391. Kraekkja 2}

$1020 \pm 110$

Charcoal from cultural layer .01 to $.02 \mathrm{~m}$ thick at depth $.05 \mathrm{~m}$ in remains of stone hut at $+1151 \mathrm{~m}$. Burnt bones.

\section{T-1513. Kraekkja 4}

$$
720 \pm 70
$$

Bone from depth $.45 \mathrm{~m}$ in bone heap outside entrance of stone hut remains at +1153m ("Hut C", Negaard, 1911).

T-1421. Kraekkja 5

Bone from depth $.20 \mathrm{~m}$ in bone heap.

T-1463. Kraekkja 6
Bone from cultural layer $.30 \mathrm{~m}$ thick at depth .20 to $.30 \mathrm{~m}$ outside supposed entrance of stone hut remains at +1151m ("Hut A", Negaard, 1911). 


\section{T-1422. Kraekkja 7}

$$
680 \pm 100
$$

Bone from depth .30 to $.40 \mathrm{~m}$ in bone heap outside entrance to S-most remains of stone hut in site at $+1153 \mathrm{~m}$, denoted "Southern locality" by Negaard (1911).

\section{T-1465. Kraekkja 8}

AD 1360

$590 \pm 100$

Bone from depth .05 to $.15 \mathrm{~m}$ in bone heap.

\section{Reindeer individual hunting series, Hardangervidda}

When local communities surrounding Hardangervidda were resettled after Black Death ca AD 1350, reindeer drive was no longer feasible; method replaced by individual trapping and hunting. Small and rather insignificant huts were built. Coll 1971 and 1972 and subm 1972 and 1973 by $\mathrm{O}$ Blehr. Comment $(\mathrm{OB})$ : dates from look-out huts, $i e$, huts situated to give hunter a good view of animal migration route. Younger than expected. This type of hut might reflect introduction of hunting with guns in area (Blehr, 1972).

\section{T-1392. Dragöynuten 1}

$$
270 \pm 70
$$

Charcoal from cultural layer $.01 \mathrm{~m}$ thick at depth $.07 \mathrm{~m}$ in remains of look-out hut at $+1210 \mathrm{~m}$ at Dragöynuten, Hol, Buskerud $\left(60^{\circ} 27^{\prime} \mathrm{N}, 7^{\circ}\right.$ $\left.42^{\prime} \mathrm{E}\right)$.

\section{T-1305. Olavsbuvatn 2}

$$
280 \pm 70
$$

Charcoal from depth $.10 \mathrm{~m}$ in fireplace in remains of look-out hut at $+1200 \mathrm{~m}$ on top of small hill near lake Olavsbuvatn, Ullensvang, Hordaland $\left(60^{\circ} 26^{\prime} \mathrm{N}, 7^{\circ} 37^{\prime} \mathrm{E}\right)$.

\section{T-1308. Dalbore 1}

$470 \pm 70$

\section{AD 1480}

Charcoal from cultural layer at depth $.10 \mathrm{~m}$ outside entrance to remains of hut at $+1150 \mathrm{~m}$ in Kjeldo, Ullensvang, Hordaland $\left(60^{\circ} 26^{\prime} \mathrm{N}\right.$, $\left.7^{\circ} 34^{\prime} \mathrm{E}\right)$.

\section{Pit fall series, Rondane}

Series dates use of 2 different types of pit falls for trapping reindeer in $\mathrm{mt}$ area Rondane; one oval shaped type with wooden walls, the other rectangular with stone walls. Coll 1967 to 1972 by Edv K Barth and Arne Skjölsvold; subm 1971 and 1972 by E K Barth, Norsk Skogbruksmus, Elverum.

\section{T-1454. Grimsdalen}

$$
\begin{array}{r}
920 \\
\text { AD } 1030
\end{array}
$$

Charred wood remains of pole from wall of oval pit fall at $+930 \mathrm{~m}$ in Grimsdalen, Dovre, Oppland $\left(62^{\circ} 05^{\prime} \mathrm{N}, 11^{\circ} 21^{\prime} \mathrm{E}\right)$. Depth ca $.25 \mathrm{~m}$ below basal surface of pit. 
T-1420. Lille Ula

Tharred wood remains

Ula Ula, Sel, Oppland $\left(61^{\circ} 51^{\prime} \mathrm{N}, 9^{\circ} 40^{\prime} \mathrm{E}\right)$. Depth $.50 \mathrm{~m}$ below basal surface.

\section{T-1128. Vulua, stone hut}

AD 1530

$420 \pm 100$

Charcoal from depth $.25 \mathrm{~m}$ in fireplace inside remains of stone hut at $+1080 \mathrm{~m}$ in Vuludalen, Fron, Oppland $\left(61^{\circ} 49^{\prime} \mathrm{N}, 10^{\circ} 02^{\prime} \mathrm{E}\right)$. Comment (EKB): remains near series of 68 oval-shaped pit falls.

\section{T-1311. Vulua/Hornflågån}

$810 \pm 70$

Humus from distinct layer $.02 \mathrm{~m}$ thick at depth $.35 \mathrm{~m}$ below basal surface at $+1300 \mathrm{~m}$ in Hornflågådalen, Fron, Oppland $\left(61^{\circ} 49^{\prime} \mathrm{N}, 9^{\circ} 57^{\prime} \mathrm{E}\right)$, from rectangular stone-walled pit fall. Comment (EKB): hypothesis: last remains from covering frame work on top of pit.

\section{T-1219. Gravhö}

AD 1600

$350 \pm 80$

Wood from a solid, longitudinal pole at base of rectangular, stonewalled pit fall at $+1300 \mathrm{~m}$ in Gravhö, Dovre, Oppland $\left(62^{\circ} 03^{\prime} \mathrm{N}, 9^{\circ} 37^{\prime}\right.$ E). Depth $.15 \mathrm{~m}$ below basal surface. Comment (EKB): hypothesis: pole preventing animals to climb up from pit.

\section{T-1218. Randen}

$450 \pm 70$

Part of solid, longitudinal pole at base of rectangular, stone walled pit fall at $+1360 \mathrm{~m}$ in Randen, Sel, Oppland $\left(61^{\circ} 52^{\prime} \mathrm{N}, 9^{\circ} 43^{\prime} \mathrm{E}\right)$. Depth $.19 \mathrm{~m}$ below basal surface.

\section{T-1217. Langglupdalen}

$1900 \pm 400$

Small pieces of wood at base of rectangular, stone walled pit fall at $+1430 \mathrm{~m}$ in Langglupdalen, Folldal, Hedmark $\left(61^{\circ} 56^{\prime} \mathrm{N}, 9^{\circ} 51^{\prime} \mathrm{E}\right)$. Sample lying on large horizontal flagstone as fundament in bottom; assumed to be remains of covering frame work on top of pit. Depth $.08 \mathrm{~m}$ below basal surface of pit. Comment (EKB): oldest known date of pit falls of this type ( $R, 1972$, v 14, p 447).

\section{T-1127. Gravhö, stone hut}

$$
\begin{array}{r}
310 \pm 70 \\
\text { AD } 1640
\end{array}
$$

Charcoal from depth $.15 \mathrm{~m}$ in fireplace inside remains of stone hut at $+1200 \mathrm{~m}$ in Gravhö, Dovre, Oppland $\left(62^{\circ} 02^{\prime} \mathrm{N}, 9^{\circ} 38^{\prime} \mathrm{E}\right)$. Comment $(\mathrm{EKB})$ : remains $500 \mathrm{~m}$ from stone wall $19 \mathrm{~m}$ long, built for trapping
reindeer.

\section{T-1419. Eldådalen wolf pit}

AD 1530

$420 \pm 140$

Wood from wolf pit with timber walls from bog at $+800 \mathrm{~m}$ at $\mathrm{N}$ Messeltseter in Eldådalen, Stor-Elvdal, Hedmark $\left(61^{\circ} 28^{\prime} \mathrm{N}, 10^{\circ} 48^{\prime} \mathrm{E}\right)$. 
Depth $.60 \mathrm{~m}$. Coll 1972 by Tore Fossum, Norsk Skogbruksmus, Elverum; subm 1972 by E K Barth and T Fossum.

\section{Miscellaneous archaeologic samples}

\section{Brennmoen series}

Charcoal from excavated house on site now uninhabited at ca $+100 \mathrm{~m}$ in Brennmoen, Skistad, Overhalla, Nord-Tröndelag $\left(64^{\circ} 25^{\prime} \mathrm{N}, 12^{\circ} 10^{\prime} \mathrm{E}\right)$. Coll and subm 1970 by Kristen R Möllenhus, DKNVS Mus, Univ Trondheim.

\section{T-967. Brennmoen II}

From lower charcoal layer.

\section{T-968. Brennmoen III}

$$
910 \pm 70
$$

From middle charcoal layer.

\section{T-1077. Brennmoen IV}

From upper charcoal layer.

$$
\begin{array}{r}
1040 \\
\text { AD } 910
\end{array}
$$

\section{Nape series, Fyresdal}

Charcoal from farm with 2 house sites at $+520 \mathrm{~m}$ in $W$ Nape, Fyresdal, Telemark $\left(59^{\circ} 10^{\prime} \mathrm{N}, 8^{\circ} 10^{\prime} \mathrm{E}\right)$. Coll 1969 by Trygve Fett; subm 1970 by Irmelin Martens, Univ Oldsaksamling, Oslo. Comment (IM): no dateable objects, House II supposedly Medieval, confirmed by dates (Martens, 1973).

\section{T-1012. House site II/1}

$560 \pm 60$

From between flagstones in fireplace in Rm III.

$$
\begin{array}{r}
\text { AD } 1390 \\
760 \pm \\
\text { AD } 1190
\end{array}
$$

T-1011. House site II/2

From small pit dug into floor.

\section{Hunn series, Borge}

Charcoal from 3 stone circles ("domarringar") in Hunn, Borge, Östfold $\left(59^{\circ} 11^{\prime} \mathrm{N}, 11^{\circ} 3^{\prime} \mathrm{E}\right)$. Subm 1971 by Heid Gjöstein Resi, Univ Oldsaksamling, Oslo.

\section{T-1101. Hunn 1}

From concentration near Stone 1 in stone circle at $+35 \mathrm{~m}$. Coll 1952 by Elizabeth Skjelsvik, Univ Oldsaksamling, Oslo.

\section{T-1102. Hunn 2}

From pit containing charcoal and fragments of burnt bones between 2 standing stones ( 5 and 6 ) in stone circle at $+35 \mathrm{~m}$. Coll 1952 by $\mathrm{E}$ Skjelsvik. 
T-1103. Hunn 3

From part of stone-packing between standing stones in stone circle at $+37 \mathrm{~m}$. Coll 1951 by E Skjelsvik.

\section{T-1104. Hunn 4}

$2250 \pm 150$

From concentration within remains of stone circle at $+33 \mathrm{~m}$. Coll 1951 by Joan Jennings, Univ Oldsaksamling, Oslo.

\section{T-1166. Hunn 5}

$$
2700 \pm 160
$$

From depth $.95 \mathrm{~m}$ near base of grave mound at $+43 \mathrm{~m}$; in layer containing charcoal, burnt bones (homo sapiens, bos taurus, ovis/capra), and a pair of bronze tweezers. Coll 1971 by H G Resi. Comment (HGR): date agrees well with assumed age of bronze tweezers from same layer.

\section{T-1066. Hufthamar}

$870 \pm 110$

\section{AD 1080}

Wood from 1 of aligned wooden poles in bog at $+30 \mathrm{~m}$ in Hufthamar, Austevoll, Hordaland $\left(60^{\circ} 10^{\prime} \mathrm{N}, 5^{\circ} 10^{\prime} \mathrm{E}\right)$. Depth $.50 \mathrm{~m}$. Coll 1971 by Kristian Jansen, Hist Mus, Bergen; subm 1971 by Björn Myhre. Comment (BM): 1st archaeol excavation of standing wooden poles in bogs, observed in different parts of $\mathrm{W}$ Norway. Medieval period probably indicates a practical function, eg, part of a fence.

\section{Mindets tomt series, Oslo}

Wooden sticks from fences or walls, covered by layers of debris. Found by excavation of townsite "Mindets tomt" at $+10 \mathrm{~m}$ in Gamlebyen, the oldest part of Oslo $\left(59^{\circ} 54^{\prime} \mathrm{N}, 10^{\circ} 46^{\prime} \mathrm{E}\right)$. Coll and subm 1971 by The Central Office Hist Monuments, Archaeol Sec, Oslo.

\section{T-1329. Mindets tomt, No. 1}

$1040 \pm 110$

From depth ca $4 \mathrm{~m}$; construction belonging to one of oldest buildings in area.

T-1330. Mindets tomt, No. 5

$$
\begin{array}{r}
910 \pm 90 \\
\text { AD } 1040
\end{array}
$$

From depth ca $4 \mathrm{~m}$ in sand layers.

T-1376. Mindets tomt, No. 2$$
\text { AD } 1040
$$

From construction belonging to one of oldest buildings in area.

\section{Isegran ships series}

Wood from 2 of 3 ships apparently sunk intentionally to block sailing channel in $\mathrm{R}$ Glomma at +2 to $+3 \mathrm{~m}$ in Isegran, Fredrikstad, Östfold $\left(59^{\circ} 10^{\prime} \mathrm{N}, 10^{\circ} 50^{\prime} \mathrm{E}\right)$. Coll 1971 by Svein Molaug, Norsk Sjöfartsmus, Oslo; subm 1971 by Univ Oldsaksamling, Oslo. Comment (SM): in shipbuilding terms, ships may be as young as dated; but it is difficult 
to associate the sinking with known historic events at such a late date (Molaug, 1972).

\section{T-1148. Isegran I}

Wood (treenails).

\section{T-1149. Isegran II}

Wood (treenails).

\section{T-1349. Verne Kloster boat}

Caulking of animal hair from wreck of ship or boat from depth $.5 \mathrm{~m}$ in drainage ditch at ca $+1.5 \mathrm{~m}$, Verne Kloster, Rygge, Östfold $\left(59^{\circ} 20^{\prime} \mathrm{N}\right.$, $10^{\circ} 40^{\prime} \mathrm{E}$ ). Coll 1972 by A E Christensen Jr, Univ Oldsaksamling, Oslo; subm 1972 by Univ Oldsaksamling. Comment (AEC): date fits within limits suggested on evidence of shipbuilding technique.

\section{T-1429. Moen log-boat}

$740 \pm 110$

Wood (Pinus) from monoxyl found at depth .5m near an old brook during drainage work in Moen, Solum, Telemark $\left(59^{\circ} 10^{\prime} \mathrm{N}, 9^{\circ} 20^{\prime} \mathrm{E}\right)$. Coll 1972 by A E Christensen, Jr; subm 1973 by Univ Oldsaksamling, Oslo. Comment (AEC): monoxyls cannot be dated on archaeol criteria.

\section{T-1348. Hellesö boat}

$$
290 \pm 100
$$

Wood (treenail) from partly submerged wreck of boat close to shore in Hellesö, Bamle, Telemark (58 $\left.50^{\prime} \mathrm{N}, 9^{\circ} 30^{\prime} \mathrm{E}\right)$. Coll 1972 by A E Christensen Jr; subm 1972 by Univ Oldsaksamling, Oslo. Comment (AEC): wreck not dateable on shipbuilding criteria.

\section{REFERENCES}

Aarseth, Inge and Mangerud, Jan, 1974, Younger Dryas endmoraines between Hardangerfjorden and Sognefjorden, Western Norway: Boreas, v 3, p 3-22.

Andrews, J T, 1969, The shoreline relation diagram: Physical basis and use for predicting age of relative sea levels: Arctic Alpine Research 1, p 67-78.

Bertelsen, Reidar, 1970, Steinhaug på Saerheim: Frá haug og heidni, bd IV, p 68-71.

Blehr, O, 1973, Traditional reindeer hunting and social change in the local communities surrounding Hardangervidda: Norwegian Archaeol Review, v 6, no. 2, p 102-112. ing bd XXXVI 1972, p $115-130$

Böe, Johs, 1942, Til högfjellets forhistorie: Bergen Mus Skr no. 21, 96 p, Bergen, 1942.

Danielsen, A, 1970, Pollen-analytical late Quaternary studies in the Ra district of Ostfold, Southeast Norway: Bergen Univ Arb 1969, Mat Nat vit R no. 14, 146 p.

Farbregd, O, 1971, Arkeologisk utgraving på A i Snillfjord 1970: Fosen Historielags Årb 1971, p 15

_. 1972a, Emballasjen like viktig som innhaldet: Nicolay, no. 12, p 14.

Gulliksen 1972b, Kolgroper og keltartidsproblem: Viking bd XXXVI 1972, p 154.

ulliksen, Steinar, 1972, Low cost electronics and a twin counter assembly: 8th internat conf on radiocarbon dating, Proc, Wellington, New Zealand, Oct 1972.

Hafsten, U, 1956, Pollen-analytical investigations on the late Quaternary development in the inner Oslofjord area: Bergen Univ Årb, Nat vit R no. 8, p 1-161. Höeg, H I, 1972, En pollenanalytisk undersökelse i Skaitidalen, Saltdal kommune, 
Höeg, H I, 1974, En pollenanalytisk undersökelse i Slidereåsen i Vestre Slidre: Viking bd XXXVIII 1974, p 137-160.

Indrelid, Svein, 1973, Hein 33-En steinalderboplass på Hardangervidda: Bergen Univ Årb, Humanistisk ser 1972, no. 1, 108 p.

Johansen, Arne, 1969, Höyfjellsfunn ved Laerdalsvassdraget I: Universitetsforlaget Bergen/Oslo, 159 p.

1972, Höyfjellsfunn ved Laerdalsvassdraget II: $\mathrm{ms}$ in prep.

Johansen, Else and Odner, Knut, 1968, Arkeologiske undersökelser på Mortensnes ved Varangerfjorden: Viking bd XXXII 1968, p 57-84.

Lundqvist, G, 1951, Beskrivning till jordartskarta över Kopparbergs Län: Sveriges Geol Unders, Ca 21, 213 p.

1969, Beskrivning till jordartskarta över Jämtlands Län: Sveriges Geol Unders, Ca 45, 418 p.

Mangerud, Jan, 1973, Hordalands natur, under og like etter siste istid: Frå Fion til Fusa, Årb for Nord- og Midt-Hordland Sogelag, 26, årg, p 7-43, Bergen, 1973.

Martens, Irmelin, 1972, Mösstrand i Telemark—en jernproduserende fjellbygd för svartedauen: Viking bd XXXVI, p 83-114.

1973, Gamle fjellgårder fra strökene rundt Hardangervidda: Univ Oldsaksamlings Arb 1970-71, p 1-84.

Moe, D, 1973a, Tilveksten av enkelte myrer på Hardangervidda: Norges Offentlige Utredninger NOU 1974: 30B, p 76-79.

1973b, Studies in the Holocene vegetation development on Hardangervidda, Southern Norway I. The occurrence and origin of pollen of plants favoured by man's activity: Norwegian Archaeol Rev, v 6, no. 2, p 67-73.

Molaug, Svein, 1972, Båtene fra Isegran: Norsk Sjöfartsmus Årsberetning 1972, 3 p.

Myhre, Björn, 1972, Bronsealders jordhauger i Etne i Sunnhordland: Arkeo, Univ Bergen 1972, no. 1, p 12.

1973a, I en åker på Gjerland i Förde: Arkeo, Univ Bergen 1973, no. 1, p 15. 1973b, Nausttuft fra eldre jernalder: Arkeo, Univ Bergen 1973, p 20.

Negaard, $\mathrm{Hj}, 1911$, Hardangerviddens aeldste befolkning. Undersökelser og fund: Bergen Mus Arb 1911, hist antikv R no 4.

Nydal, Reidar, 1965, Ten years trial and error with the $\mathrm{CO}_{2}$ proportional counting technique in Trondheim: 6 th internatl conf radiocarbon and tritium dating, Proc, Pullman, Washington, June 7-11, 1965.

Nydal, Reidar et al, 1972, Trondheim natural radiocarbon measurements VI: Radiocarbon, v 14, p 418-451.

Simonsen, A, 1971, Breiavatnet og Stavangers eldste historie: Stavanger Mus Årb 1971, p 39-49.

1972, Da böndene kom til Gjedlestadvige: Frá haug og heidni, no. 2, v IV, p 217-240 (Local archaeol paper for the Rogaland area).

Slomann, W, 1971, Gravfeltet omkring Einangsteinen i Slidreåsen i Valdres: Viking bd XXXV 1971, p 11-87.

Solberg, Ole, 1909, Eisenzeitfunde aus Ostfinmarken: Christiania, 1909.

Tallantire, P A, 1972, The regional spread of spruce (Picea abies (L) Karst) within Fennoscandia: a Reassessment: Norwegian Jour Bot, v 19, p 1-16.

Undås, I, 1950, Om morener, israndstadier, marine grenser og jordskorpas stigning ved den seinglasiale Oslofjord: Bergen Univ Årb, Mat-Nat vit $\mathrm{R}$ no. 1, 72 p.

Utne, Astrid, 1971a, En hellerbosetning fra yngre steinalder: Ottar, no. 67, p 10-24.

Utne, Astrid, 1971b, Storbathallaren i Flakstad, Vest-Lofoten: Nicolay, no. 9, p 14-16.

Vorren, Tore, 1973, Glacial Geology between Jostedalsbreen and Jotunheimen, S Norway: Norges geol unders, no. 291, p 42. 